\title{
Surveys of environmental DNA (eDNA): a new approach to estimate occurrence in Vulnerable manatee populations
}

\author{
Margaret E. Hunter ${ }^{1, *}$, Gaia Meigs-Friend ${ }^{1}$, Jason A. Ferrante ${ }^{1}$, \\ Aristide Takoukam Kamla ${ }^{2}$, Robert M. Dorazio ${ }^{1}$, Lucy Keith Diagne ${ }^{3}$, Fabia Luna ${ }^{4}$, \\ Janet M. Lanyon ${ }^{5}$, James P. Reid ${ }^{1}$
}

${ }^{1}$ U.S. Geological Survey, Wetland and Aquatic Research Center, Sirenia Project, 7920 NW $71^{\text {st }}$ Street, Gainesville, Florida 32653, USA

${ }^{2}$ Aquatic Animal Health Program, College of Veterinary Medicine, University of Florida, Gainesville, Florida 32608, USA

${ }^{3}$ African Aquatic Conservation Fund, BP 449, Ngaparou, Mbour 33022, Senegal, West Africa

${ }^{4}$ The National Center for Research and Conservation of Aquatic Mammals (ICMBio/CMA), Santos, SP, Brazil

${ }^{5}$ The University of Queensland, School of Biological Sciences, St. Lucia, Queensland 4072, Australia

\begin{abstract}
Environmental DNA (eDNA) detection is a technique used to non-invasively detect cryptic, low density, or logistically difficult-to-study species, such as imperiled manatees. For eDNA measurement, genetic material shed into the environment is concentrated from water samples and analyzed for the presence of target species. Cytochrome $b$ quantitative PCR and droplet digital PCR eDNA assays were developed for the 3 Vulnerable manatee species: African, Amazonian, and both subspecies of the West Indian (Florida and Antillean) manatee. Environmental DNA assays can help to delineate manatee habitat ranges, high use areas, and seasonal population changes. To validate the assay, water was analyzed from Florida's east coast containing a high-density manatee population and produced 31564 DNA molecules $1^{-1}$ on average and high occurrence $(\psi)$ and detection (p) estimates $(\psi=0.84$ [0.40-0.99]; $\mathrm{p}=0.99$ [0.95-1.00]; limit of detection 3 copies $\left.\mu l^{-1}\right)$. Similar occupancy estimates were produced in the Florida Panhandle $(\psi=0.79$ [0.54-0.97]) and Cuba ( $\psi=0.89$ [0.54-1.00]), while occupancy estimates in Cameroon were lower $(\psi=0.49[0.09-0.95])$. The eDNA-derived detection estimates were higher than those generated using aerial survey data on the west coast of Florida and may be effective for population monitoring. Subsequent eDNA studies could be particularly useful in locations where manatees are (1) difficult to identify visually (e.g. the Amazon River and Africa), (2) are present in patchy distributions or are on the verge of extinction (e.g. Jamaica, Haiti), and (3) where repatriation efforts are proposed (e.g. Brazil, Guadeloupe). Extension of these eDNA techniques could be applied to other imperiled marine mammal populations such as African and Asian dugongs.
\end{abstract}

KEY WORDS: Marine mammal - Multi-scale occupancy model · Salt water · Trichechus . Non-invasive detection · Quantitative PCR $\cdot$ eDNA $\cdot$ Sirenia

\section{INTRODUCTION}

Environmental DNA (eDNA) detection is a rapidly expanding technique used to non-invasively monitor cryptic, low density, or logistically difficult-to-study species, such as many marine mammal populations. Use of eDNA technology has been shown to be time

${ }^{*}$ Corresponding author: mhunter@usgs.gov and cost effective in a number of systems (Goldberg et al. 2011, Jerde et al. 2011, Takahara et al. 2012) and may be preferable to some traditional survey and detection methods (Mahon et al. 2013, Hunter et al. 2015, Thomsen \& Willerslev 2015). Water samples are most frequently used for eDNA collection, although soil, air, and food sources can also be sam-

(C) The authors 2018. Open Access under Creative Commons by Attribution Licence. Use, distribution and reproduction are unrestricted. Authors and original publication must be credited. 
pled. Genetic material is shed into the environment through feces, mucus, saliva, gametes, skin cells, and decomposing carcasses. Concentrated water samples are analyzed for minute amounts of eDNA using quantitative PCR (qPCR) and state-of-the-art digital PCR (dPCR) to detect the presence of invasive and imperiled species and to estimate occurrence and detection probabilities (Hoshino \& Inagaki 2012, Doi et al. 2015a, Hunter et al. 2015).

The 3 species in the genus Trichechus are of conservation concern. The West Indian manatee Trichechus manatus, which is listed as Vulnerable by the International Union for Conservation of Nature (IUCN), has 2 subspecies (Florida manatee T. m. latirostris and the Antillean manatee T. m. manatus), each of which is listed by the IUCN as Endangered (Deutsch et al. 2008). The West Indian manatee is federally protected under the Marine Mammal Protection Act of 1972 and the US Endangered Species Act of 1973 (Deutsch et al. 2008). The documented ranges of many West Indian manatee populations are thought to be decreasing, but are data deficient, with most of the threats being human-related (QuintanaRizzo \& Reynolds 2010). The Amazonian manatee $T$. inunguis and the African manatee $T$. senegalensis are currently listed as Vulnerable; T. inunguis populations are likely in decline, whilst population trends for T. senegalensis are unknown (Keith Diagne 2015). Many manatee populations are low in density and exist as small isolates that are not well characterized (IUCN 2008, Keith Diagne 2015). Additionally, they are often distributed across large water bodies and exhibit elusive behavior due to hunting pressure, making detection difficult with traditional methods. Occupancy (0.10 [95\% CI 0.06-0.17]) and detection (0.59 [0.48-0.70]) estimates have been generated for manatees in southern Florida, USA, using aerial survey data, and environmental and temporal covariates were found to influence distributions (Bauduin et al. 2013). Occupancy estimates were also extrapolated for Florida manatees in the Florida Panhandle (0.005 [0.001-0.024]) based on aerial survey data from the west coast of Florida; however, no manatees were detected by observers during the survey (Martin et al. 2014). Aerial surveys are costly, time consuming and dependent on weather, time of day, visibility, and observer bias; however, these data could be combined with, or supplemented by, eDNA analyses to improve detection estimates.

In combination with occupancy modeling, eDNA detection can be used to accurately estimate the likelihood of a species being present or absent in the environment, especially during population dispersal, such as contraction, expansion, or repatriation events. Statistical models of site occupancy have been extended to provide estimates of the probability of occurrence of eDNA molecules and the probability of false negatives (given eDNA presence; Schmidt et al. 2013, Hunter et al. 2015, Schmelzle \& Kinziger 2016). This information can help to make inferences about species' distribution and habitat use patterns, develop long-term management strategies, and improve natural resource decisions. Specifically, realtime qPCR or dPCR (often with detection down to a single molecule) can greatly increase the precision, sensitivity, specificity, and quantitative properties of DNA detection over traditional PCR use (Hyatt et al. 2007, Phalen et al. 2011, Takahara et al. 2012, Thomsen et al. 2012, Pilliod et al. 2013, Wilcox et al. 2013, Díaz-Ferguson et al. 2014, Nathan et al. 2014, Turner et al. 2014).

Non-invasive monitoring techniques employed in understudied areas could increase our understanding of manatee populations and permit us to characterize habitat distribution, range limits, travel corridors, or high-use sites. The Antillean subspecies population in Cuba is estimated to be around 100 manatees, although the actual size and trends are unknown (Quintana-Rizzo \& Reynolds 2010). Cuban manatees are threatened by poaching and fishing practices. In contrast, the Florida manatee subspecies is relatively well studied (Reep \& Bonde 2006). Population estimates and over-wintering sites, in which large numbers of manatees aggregate, are documented through annual state-wide synoptic surveys (Martin et al. 2015). Opportunistic observations suggest that Florida manatees are expanding their summer distribution along the Florida Panhandle in the northern Gulf of Mexico, where eDNA detection could be used to identify seasonal high-use sites and generate better estimates for occurrence probabilities for this currently low-density population. The African manatee, on the other hand, is one of the least studied marine mammals in the world, and hunting and bycatch are the primary threats to their survival despite legal protection in every range country (Trimble \& Van Aarde 2010, Keith Diagne 2015). Additionally, their presence is unknown or unconfirmed in several river systems in Central and West Africa, including within their historical ranges in Chad, Nigeria, and Ghana. Similarly, due to the dark-water habitat of the Amazon River basin, accurate population size, extent of distribution, movements, and preferred habitat for the Amazonian manatee are largely unknown; however, populations may be in decline primarily due to hunting (Marmontel et al. 2016). 
Here, we have developed droplet digital PCR (ddPCR) and qPCR eDNA assays using primers and a probe homologous to the 3 Vulnerable manatee species, including both subspecies of the West Indian manatee. The assays were then validated on field samples collected from the east coast of Florida with high manatee densities and from more sparsely populated regions in the Florida Panhandle, Cuba, and Africa. We then generated baseline occurrence and detection estimates for these locations. These estimates can be compared to other manatee populations in the future, especially those with little demographic information, such as those in the Amazonian River basin.

\section{MATERIALS AND METHODS}

\section{Tissue sample DNA extraction}

We isolated genomic DNA from the West Indian, Amazonian, and African manatee species, the Florida and Antillean West Indian manatee subspecies, and dugongs Dugong dugon using tissue previously collected from either carcasses or live animals (IACUC permit number USGS-WARC-GNV 2016-03). Extractions were conducted using a traditional phenol:chloroform:isoamyl alcohol (25:24:1 v/v) protocol (Ren- shaw et al. 2015) or a Qiagen DNeasy Blood and Tissue kit. DNA quantity was assessed using spectrophotometric absorbance. Low-retention filter pipette tips were used for all eDNA laboratory processing.

\section{Environmental DNA genus-specific primer and probe design}

The ranges for the 3 manatee species are primarily distinct from one another, except at the mouth of the Amazon River, where the West Indian and Amazonian species co-occur (Fig. 1). Therefore, markers were designed for all 3 manatee species at the genus level using a conserved cytochrome $b$ region identified in 7 published Trichechus manatus haplotypes, 4 $T$. inunguis haplotypes, and $3 T$. senegalensis haplotypes (Vianna et al. 2006). Candidate primers and probes were designed to distinguish the manatee genus from the most closely related genus in the sirenian order, the dugong, and from other members of Tethytheria, the elephants. Dugong, African elephant Loxodonta africana, and Asian elephant Elephas maximus sequences were also downloaded from GenBank. Sequence data were aligned in Geneious version 5.4.7 (Biomatters). Multiple candidate primer and probe sets were identified using

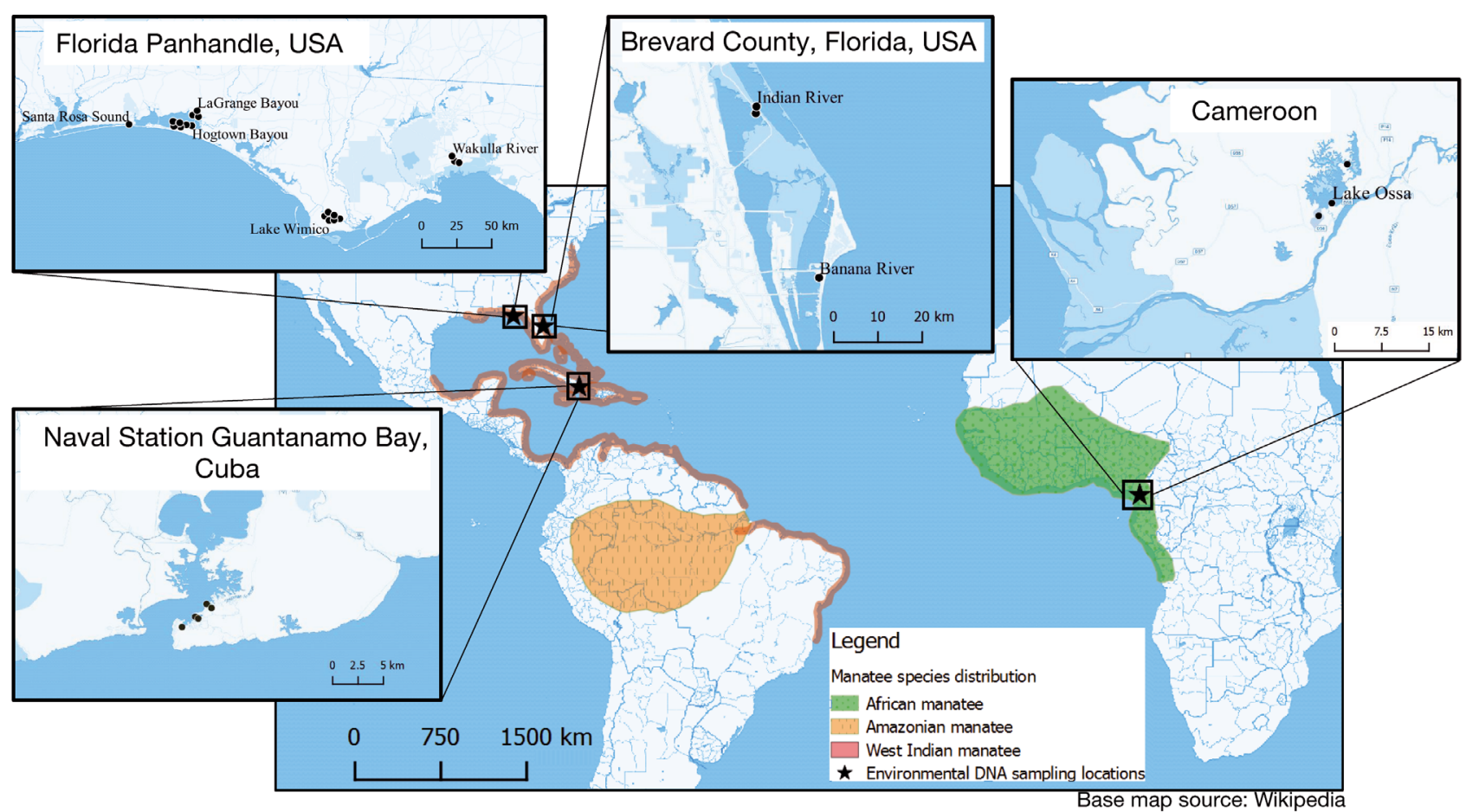

Fig. 1. Manatee species distributions (highlighted in color) and environmental DNA sampling locations (starred): Brevard County on the east coast of Florida, USA; the Florida Panhandle, Florida, USA; Guantánamo Bay, Cuba; and Lake Ossa, Cameroon 
Applied Biosystems Primer Express Software version 3.0.1 (Life Technologies). We performed an in silico analysis of the primers used for this study to identify any non-intended targets for this assay in the National Center for Biotechnology Information (NCBI) using Primer-BLAST (Ye et al. 2012).

The highly sensitive TaqMan qPCR probe was labeled at the $5^{\prime}$ end with 6-FAM and at the 3' end with a minor groove binder-nonfluorescent quencher (MGB-NFQ). Primer sets were screened for positive amplification using conventional PCR and ddPCR, as described below, on 5 genomic DNA manatee tissue samples from the African, Amazonian, Florida subspecies, and (Antillean) Brazilian subspecies, as well as from dugong samples (Fig. 2). The conventional PCR products were purified using ExoSAP-IT for PCR purification (Affymetrix) and sequenced on an $\mathrm{ABI}$ 3730XL using the Big Dye Terminator v.3.1 kit (Applied Biosystems).

\section{Synthetic gene preparation and standard dilution series}

To quantify the number of molecules in our eDNA assays, a 69 base pair (bp) gBlock Gene Fragment was synthesized (Integrated DNA Technologies), and a Qubit fluorometer (Thermo Fisher Scientific) was used to measure the concentration of the gBlock. The

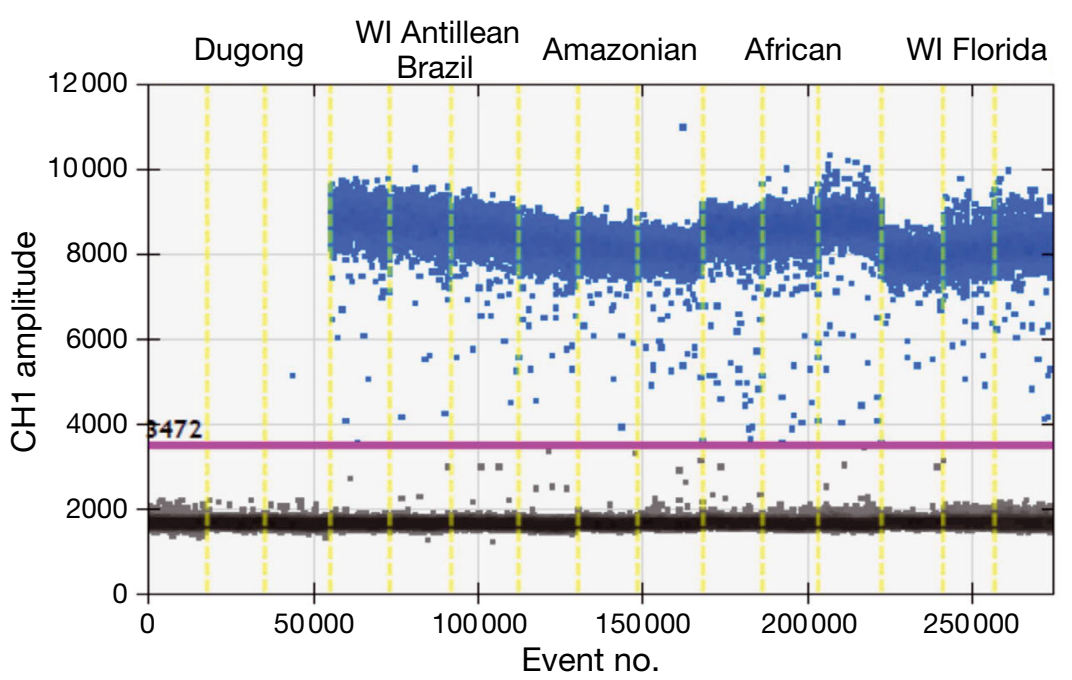

Fig. 2. Example of the droplet digital PCR raw output for the manatee environmental DNA (eDNA) assay on 1 tissue sample each from the West Indian (WI) Antillean subspecies (Brazil) and Florida subspecies, the Amazonian species, and the African species. The most common ancestor, the dugong, is not amplified by the PCR assay. Three PCR replicates (separated by the vertical bars) are shown for each of the 5 samples. Black and blue horizontal lines represent negative and positive droplets for the eDNA assay, respectively, determined by the pink threshold at the Channel 1 (CH1) fluorescence amplitude of 3472 concentration (molecules $\mathrm{\mu l}^{-1}$ ) was then determined using the molecular weight of the gBlock. We used the synthesized gene to create 1:5 standard serial dilutions at 8 dilution points between 8164.78 and 0.10 molecules $\mu \mathrm{l}^{-1}$, which were then run with 5 replicates for both qPCR and ddPCR using the methods described below.

We followed the minimum information for publication of quantitative real-time PCR experiments (MIQE) guidelines, using the lowest 6 points of the dilution series to define the assay's linear dynamic range and to determine the limit of detection (LOD) in both ddPCR and qPCR (Bustin et al. 2009). The qPCR MIQE defines the qPCR LOD as the lowest concentration in which the target was detected in $95 \%$ of the replicates; thus, LODs of $<3$ copies per PCR are not possible, assuming the Poisson distribution of DNA molecules in a sample (Bustin et al. 2009). Typically, the linear dynamic range should encompass the interval of the target nucleic acids being quantified; however, eDNA samples may have concentrations below the prescribed LOD.

\section{Droplet digital PCR}

We performed ddPCR amplification with the QX200 Droplet Digital PCR System (BioRad) for precise detection and quantification of small amounts of DNA with detection down to a single molecule. Using this method, a sample is partitioned into 10000-20000 nanofluidic droplets in which amplification takes place. This results in a random distribution of 0,1 , or several molecules of the target DNA per droplet. Each droplet is scanned to detect whether the target strand of DNA is present or absent. Our derived quantification is based on the assumption that the number of target molecules in each droplet has a Poisson distribution. Therefore, precision improves at low concentrations where it is more likely that only 1 target molecule is present in each droplet, along with the additional benefit that quantification may be more accurate than qPCR when PCR inhibitors are present due to inhibitor partitioning and binary quantification (Dingle et al. 2013, Sedlak et al. 2014, Doi et al. 2015b). 
We performed ddPCR amplification in a total reaction volume of $25 \mu \mathrm{l}$, containing $4 \mu \mathrm{l}$ of DNA, $12.5 \mu \mathrm{l}$ of ddPCR mix (BioRad), a final concentration of $250 \mathrm{nM}$ probe, and $800 \mathrm{nM}$ of each primer. To distinguish between true target negatives and PCR inhibition, we also included an internal positive control (IPC) PrimePCR Probe assay containing 0.31 or $1.00 \mu \mathrm{l}$ PreAmp and $0.20 \mu \mathrm{l}$ template (diluted 1E-07 or 1E-10; YWHAZ, Rhesus Monkey; BioRad). Droplet generation oil (70 $\mu \mathrm{l}_{\text {; }}$ Bio-Rad) was used with $20 \mu \mathrm{l}$ of the sample PCR mix to form droplets, and $38 \mu \mathrm{l}$ of this mixture was used for PCR amplification. The PCR protocol included 1 cycle at $95^{\circ} \mathrm{C}$ for $10 \mathrm{~min}$, followed by 40 cycles of $94^{\circ} \mathrm{C}$ for $30 \mathrm{~s}$ and $60^{\circ} \mathrm{C}$ for $1 \mathrm{~min}$, and finally 1 cycle at $98^{\circ} \mathrm{C}$ for $10 \mathrm{~min}$. PCR replicates $(\mathrm{N}=5)$ were performed for each of the water samples. Positive controls $(\mathrm{N}=3$ or 4) and no-template controls (NTCs; $\mathrm{N}=3$ or 4) were included on each experimental ddPCR plate. The theoretical lower limit of the final probe concentration was determined following Applied Biosystems TaqMan protocols, using dilutions ranging from 50-250 nM, in $50 \mathrm{nM}$ increments on qPCR and used on ddPCR.

Detection thresholds were set manually using QuantaSoft Version 1.7.4.0917 software (BioRad) in accordance with BioRad recommendations. Expected copy numbers were calculated for each dilution point using the synthetic gene molecular weight and Qubit measured concentration. Droplet digital PCR data were transformed to a linear relationship using a complementary log-log link function (Dorazio \& Hunter 2015).

The limit of quantification (LOQ) was based on the highest number of ddPCR positive droplets in NTCs and negative laboratory or field controls. Field controls were prepared at each site with purified water and the standard eDNA preservative. A single field control collected on the east coast of Florida contained the highest eDNA concentrations and was used to determine the LOQ. It had 3 of 5 PCR replicates with at least 1 positive droplet with the highest concentration replicate at 0.185 molecules $\mu \mathrm{l}^{-1}$. Any positive droplets in PCR replicates with a DNA concentration at or below this LOQ threshold were adjusted to 0 . All other controls tested in this study except 3 (1 NTC, 1 filtering control, and 1 negative field control) were negative. Each of these had a single positive droplet (a 'highflyer droplet' with a higher intensity than positive controls, indicating a false positive) detected in a single PCR replicate and had concentrations below the LOQ of 0.185 molecules $\mu \mathrm{l}^{-1}$, resulting in their exclusion.

\section{Quantitative PCR}

Droplet digital PCR was used in this study due to its absolute quantification, sensitivity, and ability to improve accuracy in the presence of inhibition through the partitioning of eDNA samples. However, the assay was also optimized for the GPCR platform because that platform is more widely available to the research community and better facilitates manatee research worldwide. We performed qPCR amplification with the Applied Biosystems QuantStudio 3 PCR System (Thermo Scientific) in a total reaction volume of $20 \mu \mathrm{l}$, containing $4 \mu \mathrm{l}$ of DNA, 1X PCR TaqMan Fast Advanced Master Mix (Life Technologies), a final concentration of $250 \mathrm{nM}$ TaqMan probe (Life Technologies), $1 \mu \mathrm{M}$ of each primer, and YWHAZ Rhesus Monkey PrimePCR Probe assay (IPC) containing $0.3125 \mu \mathrm{l}$ PreAmp and $0.2 \mu \mathrm{l}$ IPC template (diluted $1 \times 10^{-6}$; BioRad).

The qPCR protocol included an initial incubation at $95^{\circ} \mathrm{C}$ for $20 \mathrm{~s}$, followed by 45 cycles of denaturation at $95^{\circ} \mathrm{C}$ for $1 \mathrm{~s}$, and an extension at $61^{\circ} \mathrm{C}$ for $20 \mathrm{~s}$. To allow for minimum cycle threshold $\left(\mathrm{C}_{t}\right)$ values, the optimal final probe concentration was determined following Applied Biosystems TaqMan protocols, using dilutions ranging from 150-350 nM, in $100 \mathrm{nM}$ increments. Optimal concentrations were determined as having a lower quantification cycle and a higher $\Delta \mathrm{Rn}$ at the 45 th cycle. The linear regression calculated from the standard curves provided the slope and $y$-intercept to calculate the DNA concentration for the measured $C_{t}$ values by the Applied Biosystems QuantStudio Software v1.4. The program generated a threshold of 0.1616 , which was maintained for analysis. The synthetic gene 8-point standard curves were assessed for their conformation to the Applied Biosystems real-time PCR recommended criteria, including primer efficiency within 90-110\%, slope $-3.34 \pm 0.24$, and $\mathrm{R}^{2}$ correlation coefficient $\geq 0.99$.

\section{Environmental DNA sample collection locations}

The geographic areas where samples were collected are named in a hierarchical sampling scheme. Within each location, samples were collected at 3 to 10 sites, containing 3 or 5 field replicate samples per site for a total of 128 samples (see Table 1 for location and replicate information). Only a single species or subspecies of manatee was present at each of the locations (Fig. 1). Environmental DNA samples were opportunistically collected in 6 locations: the east 
Table 1. Manatee environmental DNA (eDNA) detections in Brevard County on the east coast of Florida (FL), USA; Florida Panhandle, FL, USA; Naval Station Guantanamo Bay, Cuba; and Lake Ossa, Cameroon. Naïve eDNA occurrence rates are given as the proportion of positive samples (1 or more PCR replicates above the limit of detection) and site (1 or more field replicate samples) over total values. Average eDNA sample concentration (including 0s) and minimum (excluding 0s) and maximum replicate value for each eDNA sample concentration per location (DNA mol $1^{-1}$ ). Of note, in the western Florida Panhandle location, 3 samples were dropped due to high inhibition, and either 4 or 5 field samples were collected per site

\begin{tabular}{|c|c|c|c|c|}
\hline Location & $\begin{array}{c}\text { Positive/total } \\
\text { samples (\% positive) }\end{array}$ & $\begin{array}{l}\text { Positive/ } \\
\text { total sites }\end{array}$ & $\begin{array}{c}\text { Average sample } \\
\text { concentration }\left(\mathrm{mol} \mathrm{l}^{-1}\right)\end{array}$ & $\begin{array}{c}\text { Min/max } \\
\text { concentration }\left(\mathrm{mol} \mathrm{l}^{-1}\right)\end{array}$ \\
\hline Brevard County, FL, USA & 15/15 (100) & $3 / 3$ & 31564 & $368 / 102438$ \\
\hline Florida Panhandle, FL, USA & $34 / 89(38)$ & $13 / 19$ & 137 & $122 / 6139$ \\
\hline Wakulla River & $13 / 15(87)$ & $3 / 3$ & 139 & $123 / 587$ \\
\hline Lake Wimico & 16/30 (53) & $6 / 6$ & 315 & $133 / 6139$ \\
\hline Western Panhandle & $5 / 44(11)$ & $4 / 10$ & 15 & $122 / 518$ \\
\hline Guantanamo Bay, Cuba & $11 / 15(73)$ & $5 / 5$ & 85 & $63 / 369$ \\
\hline Lake Ossa, Cameroon & $2 / 9(22)$ & $1 / 3$ & 492 & $126 / 4547$ \\
\hline
\end{tabular}

coast of Florida in Brevard County (May 2015); 3 locations in the Florida Panhandle (May, June, and September 2015); Naval Station Guantanamo Bay, Cuba (November 2013); and Lake Ossa, Cameroon (August 2015; Fig. 1). Salinity levels were classified at each site as fresh (0-0.5 parts per thousand [ppt]), brackish (0.5-30 ppt), or saline water (30-50 ppt).

Brevard County, on the east coast of Florida, is a year-round habitat for manatees, although the local population size has seasonal and migratory variation (Deutsch et al. 2003). A winter aerial survey estimated a minimum count of 1677 manatees in Brevard County as reported by the Orlando Sentinel (2015). We sampled at 2 saline sites: Bairs Cove and Haulover Canal (33 ppt), and 1 brackish site in Cocoa Beach (27 ppt), with 5 replicate samples each (Table 1). Manatees were observed at 2 of the sites in Brevard County: Cocoa Beach on the Banana River and Bairs Cove on the Indian River Lagoon.

In the Florida Panhandle, 92 samples were collected from both fresh and brackish habitats. The region was divided into 3 locations to standardize the geographic area with the other study locations. The 3 locations were: Wakulla River ( 0 ppt salinity), Lake Wimico $(0 \mathrm{ppt})$, and the western Florida Panhandle, which was sampled at Santa Rosa Sound (20 ppt), and in Choctawhatchee Bay, in LaGrange Bayou (10-15 ppt), and Hogtown Bayou (20-23 ppt). Five field replicates were collected at each of the 19 sites, except for LaGrange Bayou, which was sampled with 4 field replicates. Habitats included a clear, nutrient-poor aquifer-fed spring run (Wakulla River); a dark, nutrient-dense freshwater lake (Lake Wimico); and turbid estuary systems (Santa Rosa Sound, LaGrange Bayou, and Hogtown Bayou). Resampling occurred in Lake Wimico in May and June of 2015. This lake is surrounded by dense forest and contained abundant aquatic vegetation and dark water, which can indicate the presence of eDNA inhibitors. The extent of manatee use in the northern Gulf of Mexico coast is dependent on season and locale. During the warm season, Lake Wimico and the Wakulla River each have dozens of manatees using local resources, with more individuals traveling through to other destinations (Slone et al. 2017). US Geological Survey tracking data and field observations have also documented eastern Choctawhatchee Bay as a high-use area, although it is not used as frequently as the freshwater sites. Santa Rosa Sound has the lowest documented manatee use among northern Gulf sites sampled. Visual detection or known presence of manatees was documented at the Wakulla River, Lake Wimico, LaGrange Bayou, and Hogtown Bayou, but not at Santa Rosa Sound.

Water samples were collected from 5 saline sites (>35 ppt) at the Naval Station Guantanamo Bay location in southeastern Cuba, including samples from 2 sites in which manatees were visually detected at the time of sampling. Based on observations during manatee tracking studies occurring during the sampling period, the number of manatees using the bay can be assumed to be 15 to 30 individuals, and can vary seasonally.

Freshwater (0 ppt) samples $(45 \mathrm{ml})$ were collected at Lake Ossa, Cameroon, at 3 sites, with 3 field samples each. Manatees were visually identified within $10 \mathrm{~m}$ of the sampled area at 2 of the 3 sample sites at the time of sampling. The population size in the Lake Ossa location has not been determined but is estimated to be between 50 and 100 manatees (A. Takoukam pers. obs.). 


\section{Environmental DNA water collection and extraction}

We collected $950 \mathrm{ml}$ of field water samples in $1 \mathrm{l}$ DNase and RNase-free bottles (Nalgene) and preserved DNA with $1 \mathrm{ml}$ of sodium acetate $(3 \mathrm{M})$ and $33 \mathrm{ml}$ of $95 \%$ ethanol (Díaz-Ferguson et al. 2014, Moyer et al. 2014). Water was filtered immediately, filtered within $2 \mathrm{~d}$, or frozen and filtered as quickly as possible. Due to sample processing and transport challenges, only $48 \mathrm{ml}$ of water with $2 \mathrm{ml}$ of preservative was collected for the Cameroon location. We used a standard duty dry piston pump, model 2522B-01, from Welch ${ }^{\circledR}$, at approximately $26 \mathrm{~cm} \mathrm{Hg}$ vacuum. Water samples from Cuba were filtered through sterile packaged $0.45 \mu \mathrm{m}$ cellulose nitrate Nalgene filters. Nalgene filters were stored in ethanol and then DNA was isolated using the MoBio Power Water DNA isolation kit (MoBio Laboratories).

Following methodological improvements (Renshaw et al. 2015), all subsequent water samples were filtered using polyethersulfone filters ( $\mathrm{PES}$; 0.45 or $1.2 \mu \mathrm{m}, 47 \mathrm{~mm}$; Sterlitech). These filters were placed in 900 or $2000 \mu l$ Longmire's buffer (Longmire et al. 1997) and stored at $4^{\circ} \mathrm{C}$ until DNA isolation. We isolated DNA from PES filters using standard phenol chloroform methods (Renshaw et al. 2015). Phenol chloroform extracted DNA was suspended in $100 \mu \mathrm{l}$ of $1 \mathrm{X}$ low EDTA TE Buffer and quantified using an Implen NanoPhotometer ${ }^{\circledR}$. PCR inhibitors were removed from isolated DNA using the OneStep ${ }^{\mathrm{TM}}$ PCR Inhibitor Removal Kit (IRK; Zymo Research). Extracted DNA was analyzed on the ddPCR platform following the methods described earlier.

\section{Site-occupancy model estimation}

Occupancy models used the PCR replicate values to quantify the uncertainty and imperfect detection associated with eDNA collection and quantification, which in turn provided information critical to management efforts and population monitoring (Hunter et al. 2015). In brief, a three-level Bayesian occupancy model provided median estimates of detection probability (p) and occurrence probability $(\psi)$ across all sites in a location, and the average conditional probability of eDNA occurrence in a single sample $(\bar{\theta})$ (Hunter et al. 2015). Based on this model, code was run in the R software package to calculate concentrations, occurrence, and detection estimates for all locations (R Core Team 2013).
The repeated temporal sampling of Lake Wimico was assessed for changes in manatee eDNA estimates between the May and June sampling periods (Fig. S3 in the Supplement at www.int-res.com/ articles/suppl/n035p101_supp.pdf). Also, the Florida Panhandle occurrence and detection estimates were compared within the region (Fig. S4 in the Supplement). PCR inhibition levels from the different habitat types were assessed using a combination of the expected concentrations of IPC and the number of IRK columns required to remove PCR inhibitors from the sample. A sample was considered 'clean' when IPC levels were near expected concentrations.

\section{RESULTS}

Quantitative PCR forward Trich_eDNA_CytB-F (5'CGC TAA CCG CAT TCT CTT CAG-3') and reverse Trich_eDNA_CytB-R (5'-GGT AGC GAA TGA TYC AAC CAT AGT T-3') primers, and TaqMan probe Trich_eDNA_CytB-P (5'-CCC ACA TTT GCC GAG AC-3') were used to amplify a $69 \mathrm{bp}$ fragment of mitochondrial DNA. The primers and probe we selected each contained 2 to 6 sequence variants from non-target species. A single nucleotide polymorphism (SNP) was found in the Trichechus senegalensis Y01 sequence, indicating the need to sequence the gene in the target population prior to using this marker set (Vianna et al. 2006). This SNP has not been identified in the southern region of the species; however, an ambiguity code was used at that position. Dugong tested negative in the ddPCR assays (Fig. 2). Using NCBI in silico PCR, the closest matching sequences were mountainous pika (Ochotona sp.) species, which included a minimum of 2 to 3 SNPs in the primers and probe.

\section{Droplet digital PCR}

Across all samples, positive controls, and NTCs, we achieved an average of 16416 droplets per well $(\mathrm{N}=$ $833, \mathrm{SD}=2581, \mathrm{SE}=89$ ) among 14 plates, with a maximum of 22052 droplets in a well. The synthetic dilution series was tested using dilution points 1-8 (Fig. S1 in the Supplement). However, the lowest dilution point (No. 8) did not amplify across the 5 replicates. Dilution point 7 had 1 or 2 droplets in 4 replicates, and dilution point 6 had 2 to 5 droplets in all 5 replicates. The correlation coefficient for the curve was 0.99 . 


\section{Quantitative PCR standard curve and LOD estimation}

The $350 \mathrm{nM}$ probe concentration had the lowest $\mathrm{C}_{\mathrm{t}}$ (32.94) and highest $\Delta \mathrm{Rn}(4.91)$ at the 45 th cycle. However, the results for the $250 \mathrm{nM}$ probe were close, with a $C_{t}$ of 33.23 and $\Delta \mathrm{Rn}$ of 4.27 . Both were better than the $150 \mathrm{nM}$ probe concentration $\left(\mathrm{C}_{\mathrm{t}}=34.02\right.$, $\Delta \mathrm{Rn}=2.32$ ). We elected to use the $250 \mathrm{nM}$ concentration, as the cost savings over the higher concentration was preferred for comparably effective performance. The qPCR standard curve statistical criterion for the synthetic gene was met with standard dilution points 1-7 (primer efficiency 95.25\%; slope -3.44; and $\mathrm{R}^{2}$ correlation coefficient 0.993 ); no amplification was observed for the eighth dilution point (Fig. S2 in the Supplement). The qPCR LOD was at dilution 6, with an average $C_{t}$ of 40.36 , and a copy number of 13 molecules $\mu \mathrm{l}^{-1}$ (Fig. S2).

\section{Manatee eDNA detection and occurrence estimates}

The cytochrome $b$ assays successfully detected manatee eDNA in all 6 surveyed locations. All 3 Florida east coast sites were positive (average 31564 mol l-1, $\mathrm{SD}=40441$; maximum $102438 \mathrm{~mol} \mathrm{l}^{-1}$; Table 1). The average concentration was $>64$ times the other locations surveyed for eDNA. The Florida Panhandle had an average sample concentration of $137 \mathrm{~mol} \mathrm{l}^{-1}(\mathrm{SD}=634)$, with the lowest detection estimate (0.64) and moderate occurrence estimates (0.79 [0.54-0.97]; Fig. S4), with high levels of inhibition at some sites (notably in LaGrange Bayou). This was evidenced by low IPC values and the use of several IRK columns. Complete PCR inhibition after the maximum number of IRK columns resulted in exclusion of 3 samples from 1 site in LaGrange Bayou. Cuba had the lowest average sample concentration (85.4 $\mathrm{mol} \mathrm{l}^{-1}$,
$\mathrm{SD}=76$ ). However, at least 1 field sample was positive at each of the 5 sites, resulting in the highest median regional occurrence estimate (0.89 [0.541.00]) and a moderate detection estimate $(0.77$; Table 2). Cameroon had the lowest regional occurrence estimate; only a single site was positive, with 2 positive field samples with a relatively high maximum concentration of $4547 \mathrm{~mol} \mathrm{l}^{-1}$ (Table 1).

\section{DISCUSSION}

Many manatee populations are difficult to study due to low densities and the species' secretive nature. Using the eDNA assay described here, we detected the presence of manatees from as few as 3 copies $\mu l^{-1}$ of genetic material collected non-invasively from the environment. In the US, the use of eDNA technology may be beneficial in determining the distribution of expanding manatee populations along the Florida Panhandle and throughout the northern Gulf of Mexico, or by providing temporal occurrence and detection estimates for population monitoring. Detection estimates generated in this study were higher than those based on aerial survey data from the west coast of Florida ( $\mathrm{p}=0.59$ [0.48-0.70])), an area containing a large manatee population (Bauduin et al. 2013, Martin et al. 2014). Internationally, this eDNA assay could be applied in regions of the Caribbean, Central America, and Africa, where manatees are elusive possibly due to a history of hunting. Likewise, eDNA could be used for surveys of manatees in remote areas and where visual surveys are limited due to water turbidity, such as the Amazon River basin (Reynolds \& Powell 2002, Alves et al. 2016).

The quantitative assay successfully amplified DNA from tissue for all manatee species and subspecies and excluded their nearest relative, the dugong. The assay appears to be specific to manatees and does not

Table 2. Manatee environmental DNA regional Bayesian estimates of occurrence $(\psi)$, median conditional probability of occurrence in a single sample $(\bar{\theta})$, and detection probabilities (p). Posterior median and $95 \%$ credible interval (CI) are given for each parameter of the occupancy model. Locations comprise Brevard County on the east coast of Florida (FL), USA; Wakulla River, Lake Wimico, and western Florida Panhandle in the Florida Panhandle, USA; Naval Station Guantanamo Bay, Cuba; and Lake Ossa, Cameroon

\begin{tabular}{|lccccrr}
\hline Location & $\psi$ & $95 \%$ CI & $\bar{\theta}$ & $95 \%$ CI & p & $95 \%$ CI \\
\hline Brevard County, FL, USA & 0.84 & $0.40-0.99$ & 0.87 & $0.69-0.97$ & 0.99 & $0.95-1.00$ \\
Wakulla River, FL, USA & 0.84 & $0.40-0.99$ & 0.77 & $0.59-0.91$ & 0.64 & $0.53-0.75$ \\
Lake Wimico, FL, USA & 0.91 & $0.59-1.00$ & 0.53 & $0.40-0.66$ & 0.69 & $0.59-0.79$ \\
Western Panhandle, FL, USA & 0.49 & $0.20-0.82$ & 0.30 & $0.16-0.49$ & 0.53 & $0.31-0.72$ \\
Guantanamo Bay, Cuba & 0.89 & $0.54-1.00$ & 0.64 & $0.48-0.79$ & 0.77 & $0.65-0.86$ \\
Lake Ossa, Cameroon & 0.49 & $0.09-0.95$ & 0.49 & $0.17-0.91$ & 0.81 & $0.56-0.95$ \\
\hline
\end{tabular}


cross-react with DNA from other species, evidenced by the number of negative samples ranging from $27-$ $89 \%$ at each site. PCR replicates provide information needed to estimate the probability of detecting eDNA in a sample, correct for false-negative observations, and provide confidence estimates for the findings (Schmidt et al. 2013, Rees et al. 2014, Hunter et al. 2015, Lahoz-Monfort et al. 2016).

Manatee eDNA is most likely shed through excrement, with smaller contributions expected from sloughing skin, other bodily fluids, and respiratory exhalations. Typically, low concentrations of eDNA were detected, although a small number of samples contained higher levels. In contrast to manatees, fish and amphibians have a high turnover of epithelial cells because of high turnover rates of the mucoprotein slime coating and water passage over gills. More frequent shedding of eDNA in fishes may result in increased eDNA concentrations and allow for eDNA detections with smaller water volumes than used here (Klymus et al. 2015).

The assay was validated in Brevard County on the east coast of Florida, which contained relatively high densities of manatees. The sample with the highest concentration was collected from the Treasure Island Club canal, Cocoa Beach (102438 $\left.\mathrm{mol} \mathrm{l}^{-1}\right)$, and we suspect it may have contained particles of fecal material. Manatees are known to loiter in the area, often resting for extended periods of time. Further, the water does not flush at times, reducing dispersal or dilution of eDNA particles. Environmental DNA can persist in water from days to weeks and would presumably accumulate in areas experiencing low flow (Barnes et al. 2014).

The occurrence estimates in the Florida Panhandle ranged broadly (49-91\%). The western Florida Panhandle had the lowest percentage of occupied sites, while Lake Wimico and the Wakulla River had higher site occurrence. These results are in agreement with field and telemetry data indicating higher manatee use of the eastern Florida Panhandle (Slone et al. 2017). Samples collected 1 month apart in Lake Wimico showed similar estimates of occurrence (Fig. S3 in the Supplement).

Many of the brackish-water sites sampled here indicated a higher level of PCR inhibition, potentially leading to reduced detection and occurrence estimates. PCR inhibitors include humic acid, found in peat and soil, and tannins produced by pine trees, mangroves, etc. that surround water bodies (Schrader et al. 2012). The Florida Panhandle region had the lowest detection estimates (53-69\%; Fig. S4 in the Supplement), and was also highly associated with inhibited samples. The lower estimates may be due to incomplete inhibition removal despite cleaning with numerous IRK columns. On the other hand, the Florida east coast location was sampled near mangroves and estuaries with higher salinity (27-33 ppt), but had the highest eDNA concentrations. The high eDNA concentrations may have compensated for the effects of inhibitors in those samples. Improved inhibition treatment protocols and correction factors are needed for turbid eDNA samples, many of which contain high levels of organic material.

In Cuba, the relatively high occupancy rate $(89 \%)$ was expected because samples were collected in areas of suspected manatee use. However, relatively low eDNA concentrations were found $\left(85.4 \mathrm{~mol} \mathrm{l}^{-1}\right.$ average), and many samples were negative, reflecting the small number of manatees in the bay. Further, tidal flushing can increase water mixing, and warm, sunny conditions may have contributed to some eDNA degradation (Barnes et al. 2014).

The assay performed well on samples with a range of salinity concentrations, including the highly saline Cuba samples. The lowest detection estimates were found in the brackish-water habitats of the western Florida Panhandle, but those were likely affected by high PCR inhibitor levels (Table 2). The effects of salinity on detection estimates are difficult to compare in the field due to diverse environmental covariates. Ex situ analysis could be used to control covariates and test water with varying salinities, inhibitors, and eDNA concentrations simultaneously.

Due to logistical considerations, only $45 \mathrm{ml}$ of water and 3 samples site ${ }^{-1}$ were analyzed from Lake Ossa in Cameroon. While manatees were sighted frequently in the area, eDNA was only detected in 2 of 9 samples, which resulted in the lowest occurrence estimates. Interestingly, a single water sample contained highly concentrated manatee eDNA ( 4500 $\left.\mathrm{mol} \mathrm{l}^{-1}\right)$, potentially indicating the collection of fecal material. This sample contributed to the overall high detection estimates for Cameroon $(80 \%)$, and highlights the importance of large sample numbers.

The heterogeneous partitioning of eDNA in water samples is common (Pilliod et al. 2013, Moyer et al. 2014, Nathan et al. 2014, Turner et al. 2014) and supports the need for increased sample numbers and volumes for determining accurate occurrence and detection estimates. While this study used between 9 and 44 eDNA samples and 3 to 10 sites per location, additional samples across a broader geographic range are needed for more accurate results. Location-specific testing is necessary in order to achieve a high probability of DNA acquisition, but increased 
volumes ( $>45 \mathrm{ml}$ ) and sample sizes ( 30 samples) are recommended to improve the power of statistical analysis (Hunter et al. 2015). The use of digital PCR may allow for fewer samples or smaller volumes, as it affords the ability to detect single eDNA molecules and increases the dynamic range below 3 molecules reaction $^{-1}$ (the limit of qPCR; Bustin et al. 2009, Hunter et al. 2017).

Future eDNA surveys could help to delineate manatee habitat ranges, high-use areas, and seasonal population changes in threatened manatee populations. Environmental DNA could be combined with other survey techniques, such as aerial surveys, in areas where manatees are on the verge of extinction (e.g. manatees in Jamaica and Haiti) to improve conservation and management decisions. Moreover, the technique could be extended to other imperiled sirenian and marine mammal populations, such as dugongs in Asia and Africa.

Acknowledgements. We thank Dr. Robert Bonde, Amy Teague, Susan Butler, and the members of the USGS Conservation Genetics Laboratory. Sample collections and analysis were conducted under USFWS Federal Wildlife Research Permit no. MA791721 issued to the USGS, Sirenia Project. Dugong tissue samples were collected under Australian Scientific Purposes Permit no. WISP01660304, Moreton Bay Marine Park Permit no. QS2004 CVL228, and University of Queensland Animal Ethics no. ZOO ENT 34404 NSF CRL. Cameroon samples were collected under Research Permit no. 0000134/MINERESI/B00/C00/C10/C14. We thank George Kenny and Jered Jackson (NAVFAC Southeast Region), and Mike McCord and José Montalvo (NAVFAC Engineering Command-PWD Guantanamo Bay) for NSGB project logistics. NSGB activities were conducted under Department of the Navy MIPR no. N60514-12-MP-001GO. USGS authors were supported by the Survey's Ecosystems and Wildlife programs. The views expressed are those of the authors and do not represent the policies or opinions of the U.S. Department of Defense or associated military services. Any use of trade, firm, or product names is for descriptive purposes only and does not imply endorsement by the U.S. Government.

\section{LITERATURE CITED}

Alves M, Kinas P, Marmontel M, Borges J, Costa A, Schiel $N$, Araujo M (2016) First abundance estimate of the Antillean manatee (Trichechus manatus manatus) in Brazil by aerial survey. J Mar Biol Assoc UK 96:955-966

Barnes MA, Turner CR, Jerde CL, Renshaw MA, Chadderton WL, Lodge DM (2014) Environmental conditions influence eDNA persistence in aquatic systems. Environ Sci Technol 48:1819-1827

Bauduin S, Martin J, Edwards HH, Gimenez O, Koslovsky SM, Fagan DE (2013) An index of risk of co-occurrence between marine mammals and watercraft: example of the Florida manatee. Biol Conserv 159:127-136
Bustin SA, Benes V, Garson JA, Hellemans J and others (2009) The MIQE guidelines: minimum information for publication of quantitative real-time PCR experiments. Clin Chem 55:611-622

Deutsch CJ, Reid JP, Bonde RK, Easton DE, Kochman HI, O'Shea TJ (2003) Seasonal movements, migratory behavior, and site fidelity of West Indian manatees along the Atlantic Coast of the United States. Wildl Monogr 151:1-77

Deutsch C, Self-Sullivan C, Mignucci-Giannoni A (2008) Trichechus manatus. In: 2011 IUCN Red List of Threatened Species. Version 2011.1 www.iucnredlist.org/ details/22103/0 (accessed 2 Sept 2011)

* Díaz-Ferguson E, Herod J, Galvez J, Moyer G (2014) Development of molecular markers for eDNA detection of the invasive African jewelfish (Hemichromis letourneuxi): a new tool for monitoring aquatic invasive species in National Wildlife Refuges. Manag Biol Invasions 5: 121-131

* Dingle TC, Sedlak RH, Cook L, Jerome KR (2013) Tolerance of droplet-digital PCR versus real-time quantitative PCR to inhibitory substances. Clin Chem 59:1670-1672

* Doi H, Takahara T, Minamoto T, Matsuhashi S, Uchii K, Yamanaka H (2015a) Droplet digital polymerase chain reaction (PCR) outperforms real-time PCR in the detection of environmental DNA from an invasive fish species. Environ Sci Technol 49:5601-5608

* Doi H, Uchii K, Takahara T, Matsuhashi S, Yamanaka H, Minamoto T (2015b) Use of droplet digital PCR for estimation of fish abundance and biomass in environmental DNA surveys. PLOS ONE 10:e0122763

*Dorazio RM, Hunter ME (2015) Statistical models for the analysis and design of digital polymerase chain reaction (dPCR) experiments. Anal Chem 87:10886-10893

* Goldberg CS, Pilliod DS, Arkle RS, Waits LP (2011) Molecular detection of vertebrates in stream water: a demonstration using Rocky Mountain tailed frogs and Idaho giant salamanders. PLOS ONE 6:e22746

*Hoshino T, Inagaki F (2012) Molecular quantification of environmental DNA using microfluidics and digital PCR. Syst Appl Microbiol 35:390-395

*Hunter ME, Oyler-McCance SJ, Dorazio RM, Fike JA and others (2015) Environmental DNA (eDNA) sampling improves occurrence and detection estimates of invasive Burmese pythons. PLOS ONE 10:e0121655

* Hunter ME, Dorazio RM, Butterfield JSS, Meigs-Friend G, Nico LG, Ferrante JA (2017) Detection limits of quantitative and digital PCR assays and their influence in presence-absence surveys of environmental DNA. Mol Ecol Resour 17:221-229

*Hyatt AD, Boyle DG, Olsen V, Boyle DB and others (2007) Diagnostic assays and sampling protocols for the detection of Batrachochytrium dendrobatidis. Dis Aquat Org 73:175-192

IUCN (International Union for Conservation of Nature) (2008) 2008 IUCN Red List of Threatened Species. www.iucnredlist.org (accessed 19 February 2008)

Jerde CL, Mahon AR, Chadderton WL, Lodge DM (2011) 'Sight-unseen' detection of rare aquatic species using environmental DNA. Conserv Lett 4:150-157

Keith Diagne L (2015) Trichechus senegalensis (errata version published in 2016). The IUCN Red List of Threatened Species 2015: e.T22104A97168578. http:// www.iucnredlist.org/details/22104/0 (accessed 10 March 2017) 
Klymus KE, Richter CA, Chapman DC, Paukert C (2015) Quantification of eDNA shedding rates from invasive bighead carp Hypophthalmichthys nobilis and silver carp Hypophthalmichthys molitrix. Biol Conserv 183:77-84

Lahoz-Monfort JJ, Guillera-Arroita G, Tingley R (2016) Statistical approaches to account for false-positive errors in environmental DNA samples. Mol Ecol Resour 16: 673-685

Longmire JL, Maltbie M, Baker RJ (1997) Use of 'lysis buffer' in DNA isolation and its implication for museum collections. Mus Tex Tech Univ Occas Pap 163:1-4

Mahon AR, Jerde CL, Galaska M, Bergner JL and others (2013) Validation of eDNA surveillance sensitivity for detection of Asian carps in controlled and field experiments. PLOS ONE 8:e58316

Marmontel M, de Souza D, Kendall S (2016) Trichechus inunguis. The IUCN Red List of Threatened Species 2016: e.T22102A43793736. http://dx.doi.org/10.2305/IUCN.UK. 2016-2.RLTS.T22102A43793736.en (accessed 14 June 2017)

Martin J, Edwards HH, Bled F, Fonnesbeck CJ and others (2014) Estimating upper bounds for occupancy and number of manatees in areas potentially affected by oil from the Deepwater Horizon oil spill. PLOS ONE 9:e91683

Martin J, Edwards HH, Fonnesbeck CJ, Koslovsky SM, Harmak CW, Dane TM (2015) Combining information for monitoring at large spatial scales: first statewide abundance estimate of the Florida manatee. Biol Conserv 186: $44-51$

Moyer GR, Díaz-Ferguson E, Hill JE, Shea C (2014) Assessing environmental DNA detection in controlled lentic systems. PLOS ONE 9:e103767

Nathan LM, Simmons M, Wegleitner BJ, Jerde CL, Mahon AR (2014) Quantifying environmental DNA signals for aquatic invasive species across multiple detection platforms. Environ Sci Technol 48:12800-12806

Orlando Sentinel (2015) Brevard County leads way in record Florida manatee count. Orlando Sentinel Staff and Wire report, Orlando, FL. http://www.orlandosentinel.com/ news/os-manatee-count-florida-20150316-story.html

Phalen D, Slapeta J, King J, Rose K (2011) Development and validation of a rapid field test to detect the chytrid fungus Batrachochytrium dendrobatidis at a high specificity and sensitivity, for use in surveys to determine the distribution of chytridiomycosis. A report for the Australian Government Department of Sustainability, Environment, Water, Population and Communities. Australian Registry of Wildlife Health, Taronga Conservation Society Australia, Mosman

Pilliod DS, Goldberg CS, Arkle RS, Waits LP (2013) Estimating occupancy and abundance of stream amphibians using environmental DNA from filtered water samples. Can J Fish Aquat Sci 70:1123-1130

Quintana-Rizzo E, Reynolds J III (2010) Regional management plan for the West Indian manatee (Trichechus manatus). United Nations Environmental Program. CEP Techn Rep No. 48. UNEP Caribbean Environment Programme, Kingston, Jamaica

R Core Team (2013) R: a language and environment for statistical computing. R Foundation for Statistical Computing, Vienna

Reep RL, Bonde RK (2006) The Florida manatee: biology and conservation. University Press of Florida, Gainesville, FL
Rees HC, Bishop K, Middleditch DJ, Patmore JRM, Maddison BC, Gough KC (2014) The application of eDNA for monitoring of the great crested newt in the UK. Ecol Evol 4:4023-4032

Renshaw MA, Olds BP, Jerde CL, McVeigh MM, Lodge DM (2015) The room temperature preservation of filtered environmental DNA samples and assimilation into a phenol-chloroform-isoamyl alcohol DNA extraction. Mol Ecol Resour 15:168-176

Reynolds JE III, Powell JA (2002) The manatees - Family Trichechidae (Trichechus manatus, T. senegalensis, and T. inunguis) In: Perrin WF, Würsig B, Thewissen JGM (eds) Encyclopedia of marine mammals. Academic Press, San Diego, CA

Schmelzle MC, Kinziger AP (2016) Using occupancy modelling to compare environmental DNA to traditional field methods for regional scale monitoring of an endangered aquatic species. Mol Ecol Resour 16:895-908

Schmidt BR, Kéry M, Ursenbacher S, Hyman OJ, Collins JP (2013) Site occupancy models in the analysis of environmental DNA presence/absence surveys: a case study of an emerging amphibian pathogen. Methods Ecol Evol 4: 646-653

Schrader C, Schielke A, Ellerbroek L, Johne R (2012) PCR inhibitors - occurrence, properties and removal. J Appl Microbiol 113:1014-1026

* Sedlak RH, Kuypers J, Jerome KR (2014) A multiplexed droplet digital PCR assay performs better than qPCR on inhibition prone samples. Diagn Microbiol Infect Dis 80: 285-286

Slone D, Reid J, Butler S, Bonde R, Beck C (2017) Florida manatee movement and habitat use in the northern Gulf of Mexico. Bureau of Ocean Energy Management, Information Transfer Meeting, Aug. 22-24, 2017, New Orleans, LA

* Takahara T, Minamoto T, Yamanaka H, Doi H, Kawabata ZI (2012) Estimation of fish biomass using environmental DNA. PLOS ONE 7:e35868

*Thomsen PF, Willerslev E (2015) Environmental DNA - an emerging tool in conservation for monitoring past and present biodiversity. Biol Conserv 183:4-18

* Thomsen PF, Kielgast J, Iversen LL, Wiuf C and others (2012) Monitoring endangered freshwater biodiversity using environmental DNA. Mol Ecol 21:2565-2573

* Trimble MJ, Van Aarde RJ (2010) Species inequality in scientific study. Conserv Biol 24:886-890

* Turner CR, Miller DJ, Coyne KJ, Corush J (2014) Improved methods for capture, extraction, and quantitative assay of environmental DNA from Asian bigheaded carp (Hypophthalmichthys spp.). PLOS ONE 9: e114329

*Vianna JA, Bonde RK, Caballero S, Giraldo JP and others (2006) Phylogeography, phylogeny and hybridization in trichechid sirenians: implications for manatee conservation. Mol Ecol 15:433-447

*Wilcox TM, McKelvey KS, Young MK, Jane SF, Lowe WH, Whiteley AR, Schwartz MK (2013) Robust detection of rare species using environmental DNA: the importance of primer specificity. PLOS ONE 8:e59520,

* Ye J, Coulouris G, Zaretskaya I, Cutcutache I, Rozen S, Madden TL (2012) Primer-BLAST: a tool to design targetspecific primers for polymerase chain reaction. BMC Bioinformatics 13:134 